\title{
A model for Māori research for Māori practitioners
}

Paora Moyle

Paora Moyle is Ngāti Porou, a registered social worker, a member of ANZASW and a private practitioner providing social service supervision in greater Wellington. See her at: http://www.moaintheroom.maori.nz. Paora would like to acknowledge her supervisors who were a key part of her research journey, Dr Awhina English and Dr Kieran O’Donoghue.

Ko te Whetumatarau te maunga

Ko Awatere te awa

Ko Horouta te waka

Ko Ngāti Porou te iwi

Ko Tüwhakairiora te tangata

Ko Hinerupe te marae

No Te Araroa āhau

Ko Paora Moyle taku ingoa

\section{Abstract}

This article will discuss the theory and the research design used in a study as partial fulfilment of completing a Master of Social Work degree. The research design consisted of a Māori-centred approach, drawing strongly from Kaupapa Māori theory and principles, using qualitative methods. It presents the author's research journey and discusses the practical tasks involved in doing research, as encouragement and support for other Māori practitioners thinking about doing a Master of Social Work.

\section{Introduction}

Throughout the literature there are many authors who advocate for Māori practitioners to write about their experiences so that the body of Māori social work knowledge and practice is strengthened (see Bradley, 1995; Ruwhiu, 1999; Love, 2002; Walsh-Tapiata, 2003; Bell, 2006; O'Donoghue, 2003; Eruera, 2005; Hollis, 2006; Hollis-English, 2012; \& Tauri, 2010). In support of this kaupapa I wanted to share the process I underwent to complete my Master of Social Work degree. That is, the things I had to think about and had to do, including the good as well as the difficult tasks. It was a journey of personal growth as well as a contribution to Māori advancement and therefore hopefully worthy of sharing. This article presents a Māori model for research that draws strongly from Kaupapa Māori theory and principles, using qualitative methods. It is a model that is intended to resonate with other Māori practitioners thinking about doing a Master of Social Work.

\section{Kaupapa Māori Epistemology}

Kaupapa Māori epistemology has influenced this entire research project from the formation of the topic to the analysis, and the giving back to the Māori social work participants and 
the community. Kaupapa Māori is a 'home grown' form of critical theory that focuses on emancipation (Smith, 1999). It refers to a framework or methodology for thinking about and undertaking research by Māori, with Māori, for the benefit of Māori (Bishop, 1998; Smith 1999). It is a way of understanding and explaining how we know what we know and it affirms the right of Māori to be Māori (Pihama, Cram, \& Walker, 2002).

Discussion particular to Kaupapa Māori epistemology has been to a greater extent situated within academic discourse (see Durie, 1998 \& 2003; Smith, 1999 \& 2006; Pihama, 2001; Bishop, 2005). More recently, though, academics have been talking about a shift away from Kaupapa Māori being a critical theory (always focusing on the West and the oppressor) and shifting towards being more of a constructivist theory. This means Kaupapa Māori being about Māori researchers having complete autonomy without needing to conform to 'Western' expectations but instead being able to develop and enhance practices as they see fit (Hollis-English, 2012).

Pihama (2001) talks about the emancipatory intent of Kauapapa Māori theory being viewed as a decolonisation process. It is not only about theorising for the reconstruction of a Māori world, it is directly related to the practical development of sustainable interventions for whānau Māori. It is important to consistently re-assert Kaupapa Māori as being part of the context of Māori communities that consider Māori understandings as the heart of the process of research and analysis (Pihama, 2001; Smith, 2006). Eketone (2008) talks about the importance of Māori understanding and knowledge building not being located solely within Māori academia. Māori knowledge building should also come from those voices within all communities where the way of living is 'intrinsic' and 'everyday'. It acknowledges the diverse nature of contemporary Māori society as well as complementing the existing voices from Māori academia (Eketone, 2008).

\section{Māori-centred research}

Cunningham (1998) asserts that a Māori-centred approach involves Māori in all levels of the research. It includes Māori data collection and a Māori analysis, resulting in the provision of Māori knowledge. It also acknowledges that Māori knowledge is often owned and held by non-Māori (i.e. a non-Māori academic institution such as with the thesis that this research came from). A Māori-centred approach employs both Māori and non-Māori methods and contemporary research and analytical tools (Cunningham, 1998) such as interpretative phenomenological analysis (Chilisa, 2011). Other Māori researchers who have described useful models of collaborative research between Māori and non-Māori have also supported this approach (see Durie, 1996; Cram, 1997; Durie, 2001). The issue here is the need for Māori to have increased control over their own lives. This was important given the focus of this research, which was to present the stories of Māori social workers in ways that honour their realities and validate their experiences. On an individual level a researcher must at least be able to know their past in order to understand what forces shape their present life situation, in order to acknowledge others (Jackson, 1988). This is a key part of the research journey and why it becomes personal. We learn as much about ourselves as the topic and the people we are investigating. As a researcher one has to be consistently mindful of their approach and positioning when working with participants. 
Walker (2003) describes the principle of tuakana and teina and considers himself a teina to the participants. In this sense Walker (2003) becomes the learner/receiver and the participants the teachers who are gifting their stories, without which the research would not be research (Hollis, 2006). The position I adopted in this study is teina to the participants and aligns with Kaupapa Māori research. It is a position that is privileged and subjective and one that I endeavoured to remain in throughout the research journey (Walker, 2003; Smith, 2006). I agree with Smith (1999) that my approach to research as an 'insider' must be ethical, respectful, refl critical and grounded in humility. As such there was no assumption on my part that social work experience is all that was required to complete the project. Who I am and what I brought to the project in terms of experience and skills added value to it. This expression maintains the validity and legitimacy of Māori knowledge and culture (Smith, 2006).

\section{Qualitative methodology}

Nash, Munford and O'Donoghue (2005) assert that qualitative methodology acknowledges that reality is socially constructed and thus subjective experiences are valued. Furthermore, they describe qualitative methodology as being multi-method focused, an approach that studies things in their natural settings attempting to make sense of it and the meaning that people bring to them. Interviews enable a process of 'talking back' which creates the space for the legitimate exchange of views enabling the marginal and silenced voice to be heard. This fits well with Kaupapa Māori theory in terms of retrieval of space and the emancipatory purpose of Māori-centred research (Cunningham, 1998; Smith, 1999).

One-on-one, semi-structured, open and in-depth interviews were appropriate and effective qualitative methods through which it was possible to make visible the voices of the seven participants. I aimed to discover the participants' own framework of meanings based upon their professional and life experience (Walsh-Tapiata, 2003). The research approach was an open and evolving one where issues and themes were captured and built upon. The advantages of utilising this method was that it gave the participants a level of autonomy where explanations of terms could be provided, clarification sought and the participants could explain their views as much or as little as they liked (Hollis-English, 2012).

\section{Principles and ethics}

Ethical principles outlined below and promoted by Mead (1996, p. 221) in guiding Kaupapa Māori research have been identified by numerous Māori researchers (see Te Awekotuku, 1991; Bishop, 1996; Ruwhiu, 1999; Cram, 2001; Bishop, 2005; Mihaere, 2007). To demonstrate an understanding of, and a commitment to, these principles I provided a personal interpretation of them and how they actively guided me on the research journey.

\section{Aroha ki te tangata (Respect for the people you are working with)}

People are as diverse as the social constructs that make up their individual and collective world views. This principle requires me to be consciously aware of this reality and regardless of what participants bring to the research process (strengths and vulnerabilities) respect for them is actively demonstrated. In this sense I was constantly mindful of the consequences for participants if their private information was not kept confidential and secure (Te Awekotuku, 1991). Participants were carefully made aware of the research process and of how their private information would be kept secure. 


\section{Kanohi kitea (The seen face)}

This principle refers to meeting face-to-face with participants; the researcher sees them and they see the researcher, know who you are (no walls or masks). Gaining trust as a researcher is strengthened through kanohi ki te kanohi. Intention and heart are revealed here; body language and other unseen, unconscious processes of engagement are in play. Although not as authentic, there are elements of this principle present when using contemporary technology such as Skype. Although I did not use Skype as a primary interview technique for this project, it proved very useful for clarifying narratives and keeping some participants updated on the progress of the study.

\section{Titiro whakarongo kōrero (Look and listen first: Speak later)}

This principle refers to the art of patience, humility and keen observation. The researcher is a learner in a privileged situation; looking until one sees and listening until one hears, so that nothing is missed. This includes not overlooking the quieter or silent participants. This principle is about the researcher being open to all that is being offered until it becomes his/her turn to respond. In a sense this principle is about the art of capturing truth, which I felt I was successful in doing.

\section{Manaaki ki te tangata (Be generous in sharing with and hosting people)}

This refers to manaakitanga, the comfort and wellbeing of participants (i.e. they may prefer to be based in their own home when being interviewed). It also refers to the co-construction of the research journey and being accountable to the participants and their information (Smith, 1999). Be generous in sharing with and involving participants in the research process (as allowed or as consented to). This includes being creative with participants in the ways in which their stories are best captured (i.e. return their transcripts to them to ensure accurate reporting of their kōrero). Hosting also refers to the symbiotic relationship between the manuhiri/leaders out front and the workers behind the scenes making the event possible; without one another the event will fail. In terms of this study, kai was an important part of the interview process, which I provided in many of the interviews.

\section{Kaua e takahia te mana o te tangata (Take care not to trample on the mana of people)}

Creating an agreed way of working together (contract and consent) is a good means of being clear about where the research journey is going, how to get there and knowing whether the destination has been reached. 'How' is key to this principle and refers to participants being fully informed of and involved throughout the process and also being clear about issues of ownership and control of the research. This principle is about the researcher not only being mindful of it, but actively responsible and ethical because of the lasting impact that research can have on individuals and communities (Bell, 2006).

\section{Kia tūpato (Be cautious)}

This principle refers to the greatest care being taken to protect participants through confidentiality and anonymity, and about the care taken in accessing participants. It is equally about the safety of the researcher and the need to follow all legal, moral and ethical obligations of the research process (i.e. Kaupapa Māori principles, SWRB, ANZASW codes of practice and Massey University ethics committee requirements). It also means to be mindful that if the researcher is Māori, or the topic and/or participants are Māori this does not necessarily mean Kaupapa Māori research is being conducted or engaged in. This includes the researcher being reflective about their insider/outsider status (Smith, 2006). 


\section{Kaua e māhaki (Do not flaunt your knowledge)}

This principle asks the researcher to be consciously aware of the dynamics of power, politics and ethics and the impact that this has on research without grandstanding. It asks the researcher to acknowledge the co-construction of and collective ownership of the research journey. This principle also acknowledges individual diversity, allowing people to learn and express their learning in their own space and time. Finally this principle asks the researcher to continually reflect upon the question, 'On whose back am I promoting my expertise?' (Smith, 2006). This question helped me to stay on task and be mindful of authors who promote their expertise at the expense of silencing the marginalised.

\section{The principle of Te Tiriti ō Waitangi}

Pihama (2001) identified another principle to be taken into account; Te Tīriti ō Waitangi is a crucial document that defines the relationship between Māori and the Crown in Aotearoa. It affirms both the tangata whenua status of whānau, hapū and iwi in Aotearoa and their rights of citizenship. Te Tīriti therefore provides a basis through which Māori may critically analyse relationships, challenge the status quo and affirm the rights of Māori, including research that contributes to the goals of Tino-Rangatiratanga.

\section{Insider status}

Smith (2006, p. 7) points out methodological risks inherent in 'insider' research as: '... the potential for bias, lack of distance and lack of objectivity and...to mistake the research role with an advocacy role.' According to Tauri (2010) this is authoritarianism and refl the exclusionary practices that have been used by mainstream researchers to silence indigenous research. Kiro (2000) suggests that it 'takes one to know one' and Māori research is based on the principle that only an insider can understand the variances of the social phenomenon aff the participants in the research. This is not to say that non-Māori do not have a role to play in researching indigenous groups. This research attempted to contribute to the goals of Tino-Rangatiratanga by providing a Māori-centred view of standard research practices which have so far been ineff for whānau subject to care and protection involvement (Love, 2002; Tauri, 2010; Pihama, 2011). As such, it is important that a researcher clearly voices their involvement as an 'insider' to research (Smith, 2006).

As the researcher I was not detached from the topic of this investigation because I am Ngāti Porou, a member of ANZASW and a registered social work practitioner. My viewpoint and position was informed by my background as a long-serving social worker in both statutory and community settings, who actively supports Mãori advancement (Smith, 1999). I worked in CYF for a number of years as a social worker and later as a Family Group Conference (FGC) coordinator experiencing the FGC from a variety of positions. This also led to my involvement in developing the FGC model in the UK as a decision-making tool for vulnerable adults at risk of going into institutional care. It is this insider knowledge that contributed to the rapport established between the participants and me as the researcher and allowed them to talk freely about their experiences. Equally, these experiences contributed to my role as an 'outsider' in the sense that I was an independent practitioner operating outside of care and protection social work. 


\section{Access and recruitment}

I presented the research proposal to indigenous groups within ANZASW. This process was to get their blessing and tautoko for the research including access to potential participants and was an important step. Participants were interviewed as Māori practitioners and members of a professional body rather than as employees of any particular agency. This path was chosen as it kept the research away from agencies, meaning agency permission for the research did not have to be sought. It also enabled participants to be free to opt into the research and to give their consent freely from any agency obligations. Members who were interested in learning more about the study as potential participants or who had someone in mind as a participant, contacted me and were provided with an information sheet and contact details. This is a snowballing technique described by O'Leary (2011). Once I had made contact with potential participants an individual hui was arranged with each of the them in their own time and choice of meeting place.

\section{Participants and interviews}

The participants were social workers that were Māori members of ANZASW, practising in the care and protection sector in the lower North Island region. The participants had between five and 30 years' experience in care and protection and were diverse in terms of iwi affiliations, age and gender. They each had sound FGC experience through a variety of roles, including being a part of the inception of FGC, coordinators, referring social workers, cultural advisors, whānau support and/or whānau members. In terms of workplace settings they were an even spread of being based in either CYF or in health or community organisations. Drawing from their life and professional experience, the participants openly and willingly got involved in the research.

The interviews were varied in length from one hour to one and a half hours. They were individual, informal and semi-structured with open-ended questions presented as prompts. All interviews were conducted face-to-face, were audio-recorded and later transcribed, with transcripts returned to participants for checking and approval for use. Kaupapa Māori research methods were used such as koha, kai, mihi/karakia, use of te reo in conversation and a follow up hui to give back research to participants (presentation). As the interview space is where meaning is co-constructed by both the participants and the interviewer this approach was interactive and participatory. It allowed flexibility for participants to feel free to express themselves (how and what they think and feel is most significant and appropriate) whilst still allowing for the interview to remain focused on the topic area (Munford, Sanders, Andrew, Butler \& Ruwhiu, 2003; Chilisa, 2011).

It was important that project planning around timing allowed for a copy of their transcript to be returned to each participant to check for accuracy and confirm that they were comfortable for their comments to be used, to be able to make suggestions, alterations and ultimately gain their consent for use (O'Donoghue, 2010; O'Leary, 2011; Chilisa, 2011). Hutching (2004) asserts this is an integral part of the interview process because it gives the narrator autonomy and an opportunity to correct mistakes and reconsider their narrative after seeing their words typed. Each interview transcribed included the participant's words, the 'ums' and 'ughs', laughter and pauses because 'how' dialogue occurs may be important too (O'Leary, 2011). 


\section{Analysis}

Being a visual/kinaesthetic learner I chose to use O'Leary's (2011, p. 257) method of qualitative 'interpretative phenomenological' analysis. O'Leary states that the underlying logic of the process is very simple and requires the researcher to; '(1) organise their raw data; (2) enter and code that data; (3) search for meaning through thematic analysis; (4) interpret meaning; and (5) draw conclusions'. This separates the interpretation of data from the presentation of it so as to avoid any distortion of the participants' stories.

O'Leary (2011) states that at all times the researcher has to keep in mind the theory, methodological constraints and the research questions and aims. With this 'bigger picture' in mind I co-opted this method into one that works collaboratively with a Māori-centred approach, where participants have a thorough involvement in the process (Munford, et al., 2003; Hollis, 2006; Chilisa, 2011). In order to meet Kaupapa Māori principles outlined earlier, I endeavoured to be reflexive throughout the research and consciously worked to uphold my ethical and professional responsibilities as a researcher. This included being aware of the dual accountabilities that exist towards the participants and community, as well as upholding the expectations/professional standards of the ANZASW.

The first step involved transcribing the interviews, which I undertook to do as I saw it as a thorough way to become familiar with the data, identify themes and begin the analytical process. The audio recordings were listened to and subsequent transcripts were read repeatedly, over several weeks. This resulted in my knowing every silence and change in tone, laughter, sarcasm and other telling characteristics of the interviews. It may have resulted in some frustration and feelings of monotony on my part, however, this was important to recognise because without this process I could miss the intangible meanings.

Each interview transcript was then returned to the participants so that changes could be made and permission given again for its use. Once this had occurred the transcripts were sorted and coded. Rather than using Qualitative Data Analysis software (there are many available via the internet) I opted to sort and code the data manually. For example, each transcript was printed out on paper (size 14 font so that it was easier to see) that was coloured according to something memorable about the participant. Being familiar with colours helped identify participants during the sorting whilst keeping them confidential. The next stage involved manually cutting and pasting sections of transcripts onto boards representing a particular area of the research. These were then subdivided into subthemes and colour-coded by way of colour markers and highlighters.

It was a case of data dissection, sorting, coding and data reconstruction. It involved the development of categories, findings, conclusions and integration of concepts connecting to the existing literature ( $\mathrm{O}^{\prime}$ Leary, 2011). The participants were contacted about the final stages and informed about when they would receive their own copy of the final document. Throughout this whole process I kept in mind the Kaupapa Māori principle that the research is not about the researcher but about the participants and the greater cause. This ensured respect for the gift of their stories (Eruera, 2005; Hollis-English, 2012). 


\section{Limitations}

The location of the Māori analyst is important in Māori-centred research and brings with it inherent biases (Cunningham, 1998; Smith, 1999; Bell, 2006; Hollis, 2006; Hollis-English, 2012). With previous experience and personal knowledge on the topic I endeavoured to make this fact transparent and aimed to incorporate strong reflective practices throughout the course of the study. I acknowledged my bias in relation to this kaupapa and because of this positioning and the positioning of the participants, that this study had transferability in regard to its meaning for other Māori social workers (O'Leary, 2011).

At the heart of this research were the experiences of seven very experienced Māori social workers working in care and protection. The study positioned these practitioners as cultural and professional experts in their field to show how they utilised their values and beliefs in their practice according to their worldview, how they were raised and what they have experienced and learned throughout their lives (Walsh-Tapiata, 2003). Although this research was limited to seven participants, the aim was to achieve a quality of personal, professional and cultural insight in the area being explored that resonated with other Māori social workers in terms of the meaning and insights gleaned. The small number of research participants means this research is not exhaustive or representative of all Māori social workers. However, the sample was kept small because Māori-centred research assumes that knowledge is diverse; we do not seek a universal understanding. Using interpretative phenomenological analysis as a research method shows commitment to focusing specifically on individual experiences/ accounts, and its credibility is reliant on that of the participants and the research and the transferability of meaning it has for other social workers.

\section{Final reflections}

This article shared the author's research journey and discussed the practical tasks involved, as encouragement and tautoko for other Māori practitioners thinking about doing a Master of Social Work. It also presented a Māori model for research that draws strongly from Kaupapa Māori theory and principles, using qualitative methods. The research design was purposefully chosen as both Kaupapa Māori and Māori-centred research are born from a desire to use research processes by Māori, with Māori, for the benefit of Māori (Smith, 1999). This desire firmly places Māori experiences and concerns at the heart of the research project (Hollis-English, 2012).

I learned on this research journey that although it may not be traditional to record Māori knowledge, in contemporary times and with various advanced technological tools, we need to be mindful that there are many non-Māori who believe that if it's not written down then it is not valid knowledge (Tauri, 2012). This research paid tribute to Māori practitioners and at the same time challenged them to 'waha nui' and records their practice experiences. Indigenous and other critical scholars, commentators and social workers need to be aware of information provided by ministries, the policy industry and academia that collectively converge to silence the Māori voice. Don't be fooled into believing that just because a glossy report is adorned with kowhaiwhai, has smiling Māori faces and states certain statistical facts about Māori, that it is accurate. Studying for a Master of Social Work has opened my eyes and it is a wonderful way of challenging the status quo towards the development of Māori social work in Aotearoa. 
Finally, whilst reflecting upon this research journey, I am reminded of Alice Walker (n.d.) when she said, 'The most common way people give up their power is by thinking they don't have any'. I have learned that one need not carry a weapon to be a 'warrior wāhine toa' and after a lifetime of giving my power away, a pen and a Ngāti Porou heart is more than one needs to give back to her own. One is never too old to study or contribute to Māori knowledge and if this Ngāti can do it, anyone can. I now feel able to begin the next phase of this very important mahi, a PhD and hope that by discussing my journey others can see the possibilities for the development of their own practice-based research.

\section{References}

Bell, H. S. (2006). Exiting the matrix: Colonisation, decolonisation and social work in Aotearoa: Voices of Ngāti Raukawa ki te tonga kaimahi whānau (Unpublished master's thesis). Palmerston North, New Zealand: Massey University.

Bishop, R. (1996). Collaborative research stories: Whānaungatanga. Palmerston North, New Zealand: Dunmore Press.

Bishop, R. (1998). Freeing ourselves from neo-colonial domination in research: A Māori approach to creating knowledge. International Journal of Qualitative Studies in Education, 11(2), 199-219.

Bishop, R. (2005). Freeing ourselves from neo-colonial domination in research: A kaupapa Māori approach to creating knowledge. In I. Denzin \& Y. Lincoln (Eds.), Qualitative research handbook. London, United Kingdom: Sage Publications.

Bradley, J. (1995). Before you tango with our whānau you better know what makes us tick: An indigenous approach to social work. Te Komako: Social Work Review, 7, 1.

Chilisa, B. (2011). Indigenous research methodologies. London, United Kingdom: Sage Publications.

Cram, F. (1997). Developing partnerships in research: Pākehā researchers and Māori research. Sites: A Journal for South Pacific Cultural Studies, 35, 44-63.

Cram, F. (2001). Rangahau Māori: Tono tika, tona pono-the validity and integrity of Māori research. In M. Tolich (Ed.), Research ethics in Aotearoa New Zealand. Auckland, New Zealand: Longman.

Cunningham, C. (1998). A framework for addressing Māori knowledge in research, science and technology. In Te Pumanawa Hauora (Ed.), Te Oru Rangahau: Māori Research and Development Conference (pp. 387-397). Palmerston North: Te Putahi A Toi, Massey University.

Durie, M. (1996). Characteristics of Māori health research. A paper presented at Hui Whakapirpiri, Hongoeka Marae, Plimmerton. Te Pumanawa Hauora, Māori Studies, Massey University, New Zealand.

Durie, M. (1998). Mana Māori determination and development. In M. Durie, Te mana, te kawanatanga, the politics of Māori self determination (pp. 1-20). Melbourne, Australia: Oxford University Press.

Durie, A. (2001). Te renga o te era autonomy and identity: Māori educational aspirations (Unpublished doctoral dissertation). Massey University, Palmerston North, New Zealand.

Durie, M. (2003). Launching Māori futures: Nga kahui pou. Wellington, New Zealand: Huia Publishers.

Eketone, A. (2008). Theoretical underpinnings of Kaupapa Māori directed practice. MAI Review, 2008, (1). Retrieved from: http://www.review.mai.ac.nz/index.php/MR/article/view/98/106.

Eruera, M. (2005). He Kōrero Korari. Supervision for Māori: Weaving the past, into the present for the future (Unpublished doctoral dissertation). Massey University, Palmerston North. New Zealand.

Hollis, A. (2006). Pūao-te-Ata-Tū and Māori social work methods (Unpublished master's thesis). University of Otago, Dunedin, New Zealand.

Hollis-English, A. (2012). Māori social workers: Experiences within social service organisations (Unpublished doctoral thesis). University of Otago, Dunedin, New Zealand.

Hutching, M. (2004). The distance between voice and transcript. In, A. Green, \& M. Hutching, (Eds.), Remembering: Writing oral history. Auckland: Auckland University Press.

Jackson, M. (1988). Māori and the criminal justice system: He Whaipaanga Hou: A new perspective (Parts I E II). Wellington: Department of Justice.

Kiro, C. (2000). Māori research and the social services: Te puawaitanga o te tohu. Te Komako, Social Work Review, $7(4), 26-32$.

Love, C. (2002). Māori perspectives on collaboration and colonisation in contemporary Aotearoa/New Zealand child and family welfare policies and practices. In Partnerships for children and families project. Wilfred Laurier University, Ontario, Canada. Retrieved from: http:/ / www.quartetfest.ca/documents/7201/Maori_perspectives.pdf.

Mead, A. (1996). De-colonisation and identity: The bridge to unite or divide women. In S. Olsson \& N. Stirton (Eds.), Women in leadership: Power and practice (pp. 49-62). Palmerston North: Massey University, New Zealand.

Mihaere, R. (2007). Māori cultural identity and Māori offering (Unpublished master's thesis). Victoria University of Wellington. Wellington, New Zealand.

Munford, R., Sanders, J., Andrew, A., Butler, P. \& Ruwhiu, L. (2003). Action research with families/whānau and communities. In R. Munford \& J. Sanders (Eds.) Making a difference in families: Research that creates change (pp. 93-112). Australia: Allen \& Unwin. 
Nash, M., Munford, R. \& O'Donoghue, K. (2005). Introduction: Integrating theory and practice. In M. Nash, R. Munford \& K. O’Donoghue (Eds.), Social work theories in action (pp. 15-28). London, England: Jessica Kingsley.

O'Donoghue, K. (2003). Restorying social work supervision. Palmerston North, New Zealand: Dunmore Press.

O'Donoghue, K. (2010). Towards the construction of social work supervision in Aotearoa New Zealand: A study of the perspectives of social work practitioners and supervisors (Unpublished doctoral dissertation). Massey University, Palmerston North, New Zealand.

O'Leary, Z. (2011). The essential guide to doing research. London: Sage Publications.

Pihama, L. (2001). Tihei mauri ora honouring our voices: Mana wähine as a kaupapa Māori theoretical framework (Unpublished doctoral dissertation). University of Auckland, Auckland, New Zealand.

Pihama, L. (2011). A conversation about Kaupapa Māori theory and research. In Hutchings, J., Potter, H., \& Taupo, K. (Eds,) Te Wahanga. (2011). Kei tua te pai hui proceedings: The challenges of Kaupapa Māori research in the 21st century. Pipitea Marae, Wellington, New Zealand.

Pihama, L., Cram, F., \& Walker, S. (2002). Creating methodological space: A literature review of Kaupapa Māori research. Canadian Journal of Native Education, 26, 30-43.

Ruwhiu, L. (1999). Tepuwaitanga o te ihi me te wehi. The politics of Māori social policy development (Unpublished doctoral dissertation). Massey University, Palmerston North, New Zealand.

Smith, L. T. (1999). Decolonising methodologies research and indigenous people. Dunedin: University of Otago Press.

Smith, L. T. (2006). Researching in the margins: Issues for Māori researchers - A discussion paper. In C. Aspin (Ed.), Alternative: An International Journal of Indigenous Scholarship (pp. 4-27). Auckland: University of Auckland.

Tauri, J. (2010). Indigenous perspectives and experience: Māori and the criminal justice system. In J. Tauri, Introduction to criminological thought, (pp. 129-145). Retrieved from http://eprints.qut.edu.au/47697/.

Tauri, J. (2012). The indigenous criminologist. Retrieved from http://juantauri.blogspot.co.nz/2012/03/media-politics-and-darkies-behaving.html.

Te Awekotuku, N. (1991). He tikanga whakaaro: Research ethics in the Māori community: A discussion paper. Wellington: Manatu Māori: Ministry of Māori Affairs.

Walker, A. (n.d.). Women's history. Retrieved from http://womenshistory.about.com/od/alicewalker/a/Alice-Walker.htm.

Walker, P. (2003). Partnership models within a Māori social service provider. Dunedin, New Zealand: University of Otago.

Walsh-Tapiata, W. (2003). A model for Māori research: Te whakaeke i te ao rangahau o te Māori. In R. Munford \& J. Sanders (Eds.) Making a difference in families: Research that creates change (pp. 55-73). Australia: Allen \& Unwin. 